\title{
Magnetic Nanoparticles Applications for Amyloidosis Study and Detection: A Review
}

\author{
Jonathan Pansieri ${ }^{1,+}{ }^{+}$, Matthieu Gerstenmayer ${ }^{2}$, François Lux ${ }^{3}$, Sebastien Mériaux ${ }^{2}$, \\ Olivier Tillement ${ }^{3}$, Vincent Forge ${ }^{1}$, Benoit Larrat ${ }^{2}$ and Christel Marquette ${ }^{1, *}$ (i) \\ 1 Laboratoire de Chimie et Biologie des Métaux, Université Grenoble Alpes, CNRS, CEA, 17 Rue des Martyrs, \\ CEDEX 9, 38041 Grenoble, France; jonathan.pansieri@umu.se (J.P.); vincent.forge@cea.fr (V.F.) \\ 2 NeuroSpin, CEA, Université Paris-Saclay, 91191 Gif-sur-Yvette CEDEX, France; \\ matthieu.gerstenmayer@cea.fr (M.G.); sebastien.meriaux@cea.fr (S.M.); benoit.larrat@cea.fr (B.L.) \\ 3 Université Lyon, Université Claude Bernard Lyon 1, CNRS, Institut Lumiére Matiére, F-69622 Lyon, France; \\ francois.lux@univ-lyon1.fr (F.L.); olivier.tillement@univ-lyon1.fr (O.T.) \\ * Correspondence: christel.marquette@cea.fr; Tel.: +33-4-3878-5302; Fax: +33-4-3878-5487 \\ † Present address: Department of Medical Biochemistry and Biophysics, Umeå University, \\ 90187 Umeå, Sweden.
}

Received: 31 August 2018; Accepted: 16 September 2018; Published: 18 September 2018

check for updates

\begin{abstract}
Magnetic nanoparticles (MNPs) have great potential in biomedical and clinical applications because of their many unique properties. This contribution provides an overview of the MNPs mainly used in the field of amyloid diseases. The first part discusses their use in understanding the amyloid mechanisms of fibrillation, with emphasis on their ability to control aggregation of amyloidogenic proteins. The second part deals with the functionalization by various moieties of numerous MNPs' surfaces (molecules, peptides, antibody fragments, or whole antibodies of MNPs) for the detection and the quantification of amyloid aggregates. The last part of this review focuses on the use of MNPs for magnetic-resonance-based amyloid imaging in biomedical fields, with particular attention to the application of gadolinium-based paramagnetic nanoparticles (AGuIX), which have been recently developed. Biocompatible AGuIX nanoparticles show favorable characteristics for in vivo use, such as nanometric and straightforward functionalization. Their properties have enabled their application in MRI. Here, we report that AGuIX nanoparticles grafted with the Pittsburgh compound B can actively target amyloid aggregates in the brain, beyond the blood-brain barrier, and remain the first step in observing amyloid plaques in a mouse model of Alzheimer's disease.
\end{abstract}

Keywords: magnetic nanoparticles; amyloidosis; Alzheimer's diseases; targeted nanoparticles; medical imaging

\section{Introduction}

Amyloidoses can be defined as a large group of diseases characterized by soluble peptides or proteins aggregation in insoluble and very stable structures. They are composed of filamentous and unbranched architectures with $\beta$-sheets, so-called amyloid fibers. They are supplemented by small protein derivatives, made of two to six peptides or proteins, known as oligomers [1]. So far, in human pathology, 36 proteins have been identified to be amyloidogenic [2]. They are involved in a large panel of systemic, sporadic, or hereditary disorders with no structural or functional link. Obviously, their detection and characterization remain an important clinical challenge in various disorders for diagnosis and treatment. Various amyloid proteins are involved in metabolic diseases, such as $\beta_{2}$-microglobulin [3] in hereditary visceral amyloidosis, calcitonin [4] in carcinoma of the thyroid, and islet amyloid polypeptide (IAPP) [5] in type 2 diabetes. Some other amyloid 
proteins can spontaneously form aggregates, such as fragments of apolipoproteins (ApoAI, ApoAII, ApoCII), with deposition in many organs and that are linked to atherosclerosis [6,7]. A third group of diseases related to amyloid deposits concerns neurodegenerative diseases, such as amyloid $\beta(A \beta)$ in Alzheimer's disease (AD), $\alpha$-synuclein ( $\alpha$-syn) in Parkinson's disease (PD), or prion protein $(\operatorname{PrP})$ in Creutzfeldt-Jakob disease, which are the most studied amyloidoses due to their major clinical impacts [8]. Alzheimer's disease affects 47 million people around the world [9] and is characterized by a progressive cognitive impairment without reliable early diagnosis nor efficient treatment. Moreover, one of the main issues concerning these neurodegenerative diseases comes from the limited ability of drugs to reach the brain due to the blood-brain barrier (BBB), which is the physiological barrier that separates blood vessels from cerebral parenchyma [10].

In this context, in the last twenty years, nanotechnologies has become a very promising field in modern medicine in general and in the amyloidosis field in particular. Indeed, a large diversity of organic and inorganic functionalized nanomaterials is already used in clinical research [11]. The development of nanoparticles (NPs) at the nanometer scale (typically 10-300 nm) has become a front-line tool because of their high versatility in terms of composition, shape, size, and functionalization. This opens up new possibilities in a number of applications, such as disease therapy and disease diagnosis, including magnetic resonance imaging. The combination of magnetic properties and controlled surface functionalization allows for the design of sensing nanoparticles for analytes [12,13] (DNA and protein target detection), pathogens [14], such as bacteria and circulating tumoral cells [15], and amyloid peptides or protein aggregates [16]. Recently, magnetic NPs (MNPs) have also become interesting tools by integration into transducer materials using an external magnetic field for active detection on various surfaces. Thus, MNPs and a wide range of properties of molecules may be combined to increase the sensitivity of sensors as magnetic field devices, piezoelectric devices [17], electrochemical biosensors [18,19], and optical devices [20,21]. Concerning amyloidosis, NPs are promising biosensors as imaging agents for early diagnosis or therapeutic follow up [22] or as drug carriers with specific amyloid inhibitors with controlled release [23].

Magnetic nanoparticles (MNPs) were notably highlighted [24] because of their intrinsic magnetic properties and remain very useful tools for non-invasive MRI. In addition, some MNPs have shown potential properties to overcome certain biological and physical barriers, such as the BBB [25], and have proved their usefulness with tissue repair and hyperthermia properties [26]. MNPs gather superparamagnetic iron oxide nanoparticles (SPIONS), NPs with a metallic core (cobalt, zinc, nickel ... ), and other nanoparticles coated with magnetic material (silica NPs coated by gadolinium chelates or with iron ... ) [27]. In the framework of in vivo use, MNPs need to be properly designed to conciliate in situ detection by medical imaging, biological barrier crossing, and other transport restriction in biological tissues. Thus, fundamental requirements need to be fulfilled [28]: a biocompatibility with no or minimal toxicity for patients with a minimal accumulation within the liver; total body elimination of MNPs through the kidney; and the ability to reach their target through blood circulation while keeping their intrinsic magnetic and targeting properties. For example, the MNPs' size is an important factor for their ability to cross cells and biological barriers and is more often inversely related to their potential in vivo toxicity [29]. Even if this parameter depends on the MNP's metallic atom, charge, and functionalization, it is believed that $<10 \mathrm{~nm}$ particles are the best for intravenous (i.v.) administration [29,30].

In this review, we summarize MNPs designed against various amyloidosis-related diseases for biomedical applications, taking into account that neurodegenerative diseases are more often priority targets. This purpose includes MNPs as detection platforms by sensitive imaging techniques mostly implicated in the fundamental understanding of amyloid aggregation as well as in amyloid detection and quantification for diagnosis and as an indicator for therapy follow up (Figure 1). 


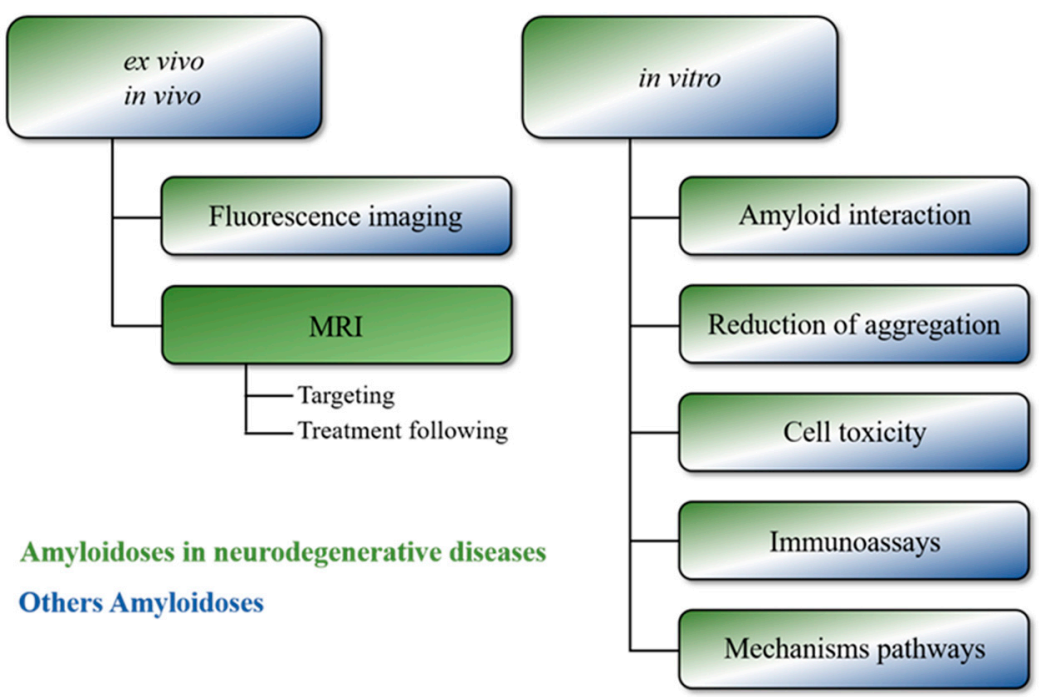

Figure 1. Principal insights of magnetic nanoparticles (MNPs) applications in other amyloidoses fields.

\section{MNPs for the In Vitro Investigation of Amyloid Deposition Mechanisms}

The formation mechanisms of amyloid aggregates are highly complex and still widely studied. Nowadays, the simplified phenomenon of nucleation-polymerization proposed in the 1980s [31] seems to be supplemented by several concomitant processes proposed in the literature [32-37]. Even if all amyloid fibers share a common $\beta$-sheet structure, the pathways leading to their formation are numerous. Fibrillogenesis and oligomerization can be initiated by denatured proteins that are fully or partially folded, preformed fibers (seeding), and/or by amorphous aggregates. Moreover, the mechanisms and kinetics of aggregation are closely linked. They depend on various favorable factors (temperature, concentration, $\mathrm{pH}$... ) and on the diversity of interaction mechanisms (co-aggregation of different amyloid proteins, seeding effect, metal ion presence ... ) [36]. Thus, a better understanding of these mechanisms can be helpful for the diagnosis and the treatment of these disorders and can be related to disease incidences. Interestingly, MNPs without amyloid-specific functionalization constitute efficient tools to study, in vitro, amyloid protein aggregation by controlling the self-assembly of amyloid proteins. Indeed, MNPs may delay, inhibit, or increase amyloid deposition and there is great potential to understand their mechanisms of action as precursors in therapeutic applications (Figure 2).

\subsection{MNPs for the Understanding of A $\beta$ Fibrillation}

Iron oxide NPs, especially Ultrasmall SuperParamagnetic Iron Oxides (USPIOs) and SPIONs of 10-150 nm diameter [38], show an impact on various amyloid proteins' aggregation, especially $\mathrm{A} \beta$. These MNPs are made of a core shell of magnetite $\left(\mathrm{Fe}_{3} \mathrm{O}_{4}\right)$, maghemite $\left(\gamma-\mathrm{Fe}_{2} \mathrm{O}_{3}\right)$, or a combination of both, generally coated with biocompatible polyethylene glycol (PEG). This PEG coating acts as a shield against the hydrophobic properties of some cells while helping NP synthesis, but Cheng et al. showed that it might be indirectly responsible for increased cytotoxic effects due to linkage with 1-éthyl-3-(3-diméthylaminopropyl)-carbodiimideN-hydroxysuccinimide (EDC-NHS) [39]. However, MNPs may disturb the formation mechanisms, kinetics, and cytotoxicity of amyloid aggregates by directly affecting their structures [40-47]. Thus, highly concentrated, positively charged PEGylated-SPIONs accelerate A $\beta$ aggregation, whereas ones of low concentration delay it $[40,41]$. Otherwise, at the same high concentration, negatively charged USPIOs promote less A $\beta$ fibrillation. These interesting results could be useful to investigate $A \beta$ mechanism pathways (control of $A \beta$ fibrils' nucleation and elongation thanks to the dual effect of SPIONs coated with positive charges) and for clinical use (a small number of side effects from negatively charged SPIONs) [40]. A previous study confirms that low-concentration MNPs may be a critical factor for in vivo applications by enhancing 
$\mathrm{A} \beta$ fiber formation with titanium oxide $\mathrm{NPs}\left(\mathrm{TiO}_{2} \mathrm{NPs}\right)$ [47]. Moreover, MNP conjugates can play a protective function for cells, as has been shown by using SPIONs-heparin, which reduces the toxicity of $A \beta$ aggregates in vitro for neuronal cells with a paradoxical acceleration of $A \beta$ fiber formation [43]. These results suggest that MNPs can change the A $\beta$ amyloid aggregates' conformation to a less toxic pathway without avoiding their aggregation.

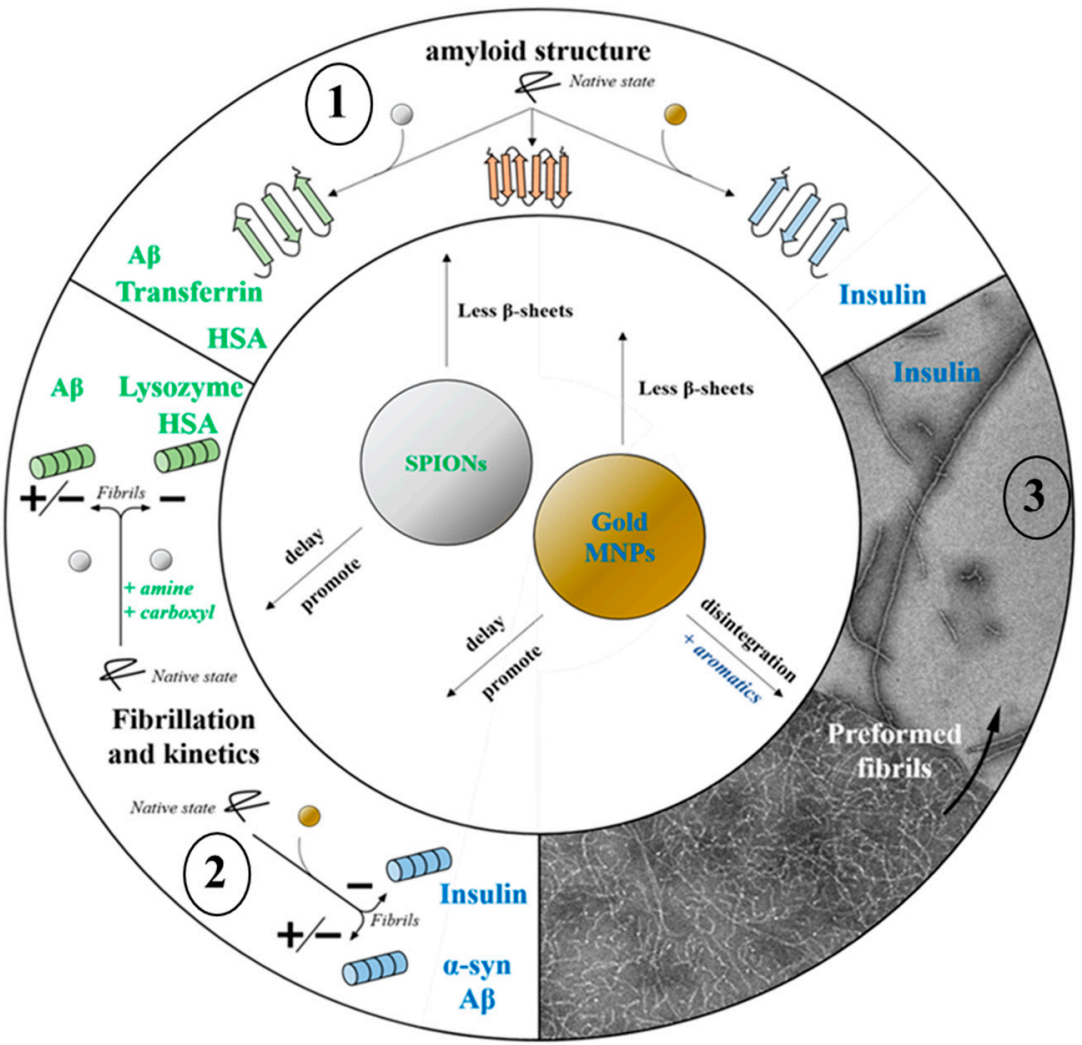

Figure 2. MNPs impacts on various in vitro amyloid aggregates. According their size, shape, charge, and type of functionalization, MNPs can: (1) affect amyloid structure at the protein level by decreasing $\beta$-sheet content; (2) inhibit, delay, or promote protein fibrillation and elongation into fibers; and (3) promote disassembly of amyloid fibers. HSA, human serum albumin.

In a different way, MNPs have a great potential to investigate oligomer formation mechanisms and to measure in vivo oligomer levels [48], the oligomers being the most toxic form of amyloid deposits [49]. The hydrophobic environment of gold nanoparticles (AuNPs) can be used as an interface to indirectly design specific oligomer antibodies [50] by mimicking $A \beta$ oligomerization of the spherical amyloid oligomers on their surface. A combination of an $\mathrm{A} \beta$ peptide with $\mathrm{TiO}_{2} \mathrm{NPs}$ is able to enhance $\mathrm{A} \beta$ oligomers production thanks to an equilibrium between $\mathrm{TiO}_{2} \mathrm{NPs}-\mathrm{A} \beta$ interaction and $\mathrm{A} \beta$ oligomers found in solution [47]. In this case, MNPs could be useful to investigate the mechanisms of amyloid oligomers production.

\subsection{MNPs for the Control of Various Amyloidogenic Proteins' Assembly}

The most frequent outcome of studies on various amyloid proteins follows the same ascertainments, with an effect on nucleation and growth rate with or without an effect on preformed fibers. Hsieh et al. shows that AuNPs can affect insulin fibril formation by delaying fibrillation and modifying the elongation of fibers to make them much shorter and more compact [51]. These results suggest that MNPs can disturb the self-assembly process by acting directly on the $\beta$-sheet core. In addition, their functionalization with aromatic aminoacids may destabilize these insulin fiber architectures and may even trigger their disassembly in solution [52]. In contrast, similar kinetics 
assays, performed with AuNPs on $\alpha$-syn proteins, showed faster and higher fibrillation inversely dependent on the nanoparticle size [53].

SPIONs also disturb hen egg white lysozyme fibrillogenesis, slowing nucleation and amyloid fibril elongation, and reduce the toxicity of neuroblastoma and fibroblast cells [42]. Using Thioflavin T (ThT) fluorescence measurements, another study showed that $\mathrm{MnFe}_{2} \mathrm{O}_{4} \mathrm{MNPs}$ functionalized with amine and carboxylate drastically inhibit human serum albumin (HSA) fibrillation [54]. Indeed, the reduction of ThT fluorescence intensity indicates a decrease in $\beta$-sheet content in HSA fibers, as this molecule is known to interact with cross- $\beta$-sheets and thus is used for experimental amyloid aggregation detection. Skaat et al. go further and show that fluorinated $\gamma-\mathrm{Fe}_{2} \mathrm{O}_{3} \mathrm{MNPs}$ inhibit insulin aggregation by delaying the $\alpha$-helix to $\beta$-sheet structure transition due to their strong hydrophobic character [55]. Thus, MNPs can change also the morphology of amyloid fibers by acting directly on monomers or the protein structure as shown by irreversible changes in transferrin conformation, an amyloid protein involved in several disorders $[45,46]$ : addition of SPIONs affects directly the protein folding that occurs before reaching the pathological forms.

\section{MNPs Functionalization for the Detection of Amyloid Aggregates}

Nowadays, MNPs are used as biosensors for fundamental research and preclinical applications. The basic idea is to use their magnetic properties for their detection, strengthened by coupling with amyloid ligands on MNP surfaces, to target an amyloid burden. A large panel of ligands already exists and various detection techniques can be applied (spectroscopy, electrochemiluminescence [56], ELISA, fluorescence imaging ... ) thanks to MNPs' versatility.

\subsection{Congo Red and Thioflavin Derivatives Dyes}

Congo Red and the previously mentioned polar molecule ThT were the first known molecules tested for the in vitro detection of amyloid deposits. They are able to inhibit a lot of the formation of oligomers and fibers while stabilizing the monomeric and partially folded forms. In this context, iron oxide NPs doped with Thioflavin have been recently synthesized, but have not yet been fully tested on amyloid aggregates [57]. Indeed, these molecules have barely been used for grafting onto MNPs for medical purposes as Congo red is potentially toxic in vivo and some chemical modifications permit us to increase the affinity and stability of ThT. However, 2-(4'-[11C]methylaminophenyl)-6-hydroxybenzothiazole, one of ThT's neutral derivatives, the Pittsburgh compound B (PIB), constitutes one of the best targeting molecules for the detection of various amyloid deposits [58]. Thus, to date, the ${ }^{11} \mathrm{C}$-PIB probe is the standard agent for AD diagnosis by PET imaging [59]. However, studies have reported that unspecific ${ }^{11} \mathrm{C}$-PIB labelling is detected in the brain of healthy patients, raising the question of its efficiency for early diagnosis [60]. Recently, Gd ${ }^{3+}$-based silica NPs functionalized with PIB (called Gd(DOTA)PEG-PIB) have been shown to interact with various amyloid fibers, i.e., the A $\beta$, IAPP, and transthyretin (TTR) amyloid fibers, and spectroscopy measurements of PIB fluorescence display affinities that remain 3 to 4 orders of magnitude [16] below those of free PIB or ${ }^{11}$ C-PIB used in PET imaging [61].

\subsection{Peptides Derived from Amyloid Proteins}

In order to add a specific recognition of an amyloid protein, numerous research projects synthesized MNPs grafted with amyloid proteins or a short peptide derived from protein sequences. Monocrystalline iron oxide NPs (MIONs) and $\mathrm{Gd}^{3+}$-based NPs grafted with the entire $A \beta_{1-40}$ protein [62] show great affinities for $A \beta$ deposits by ELISA, with dissociation constant (KD) values in the 100-nM range. However, this type of grafting obviously accelerates the fibrillation [55]. Thus, shorter peptides from amyloid sequences make them more suitable for economical and straightforward grafting and have a small immunogenic reaction $[63,64]$. This type of peptide can be selected by phage display to target amyloid aggregates, and most studies involve $A \beta$ amyloid proteins. A large number of them directly comes from the $\beta$-sheet structure buried in their hydrophobic 
core. AuNP conjugates with CLPFFD-NH2 adhere to A $\beta$ fibers with good affinity and stability [65], as do fluorinated LPFFD-iron oxide NPs conjugates, supplemented in this case by an inhibition of A $\beta$ fibril formation, with a delay of up to three days $[55,66]$. Moreover, we showed a specific recognition of $A \beta$ fibrils and deposits by Gd-based MNPs conjugates (Gd(DOTA)PEG) grafted with the peptide KLVFF or the peptide LPFFD using fluorescence spectroscopy and fluorescence imaging on AD mice tissues [67]. Their specificity toward $A \beta$ deposits was confirmed by demonstrating their lack of interaction with other types of amyloid fibers, i.e., TTR and IAPP fibers.

Interestingly, Xia et al. go further by developing a network of silver nanoparticles (AgNPs) grafted with $\operatorname{PrP}(95-110)$ peptides, and used them as redox reporters to specifically detect the oligomer form of $A \beta$ by high-sensitivity electrochemistry [68]. The method consists of using a AgNPs network and a cellular prion protein (PrPc), a specific receptor of $A \beta$ oligomers. PrPc is coupled with adamantine (Ad) on a $\beta$-cyclodextrin electrode's surface, which produces an electrochemical signal that is drastically amplified thanks to the redox reaction $\mathrm{Ag} / \mathrm{AgCl}$ due to $\mathrm{AgNPs}$. When $\mathrm{A} \beta$ oligomers interact with the Ad-PrPc surface, the electrochemical signal significantly decreases because less AgNPs are binding. This interesting work, with a limit of detection below $10 \mathrm{pM}$, could be used to precisely quantify $\mathrm{A} \beta$ oligomers in cerebrospinal fluid in the case of $\mathrm{AD}$ [69].

\subsection{Antibodies and Nanobodies}

Composites with anti-mouse IgG on AuNP surfaces may be used as a sensitive in vitro immunosensor platform, providing a great potential tool for clinical early Parkinson's disease (PD) detection thanks to the analysis of low abundant $\alpha$-syn deposits [70]. Another study goes further, using SPIONs grafted with monoclonal antibodies against $\alpha$-syn, and permits us to differentiate PD dementia from PD by the evaluation of plasma $\alpha$-syn [71]. In the same way, Wang et al. designed an immunosensor based on zinc MNPs, functionalized with both luminol and an anti-A $\beta$ antibody, to specifically detect $A \beta$ aggregates by electrochemiluminescence [56]. Others show that MIONs coated with the antibody anti-A $\beta_{42}$ can specifically detect and bind to cerebrovascular $\mathrm{A} \beta$ deposits in leptomeningeal vessels in an AD mice model, following their injection, and they could be detected in vivo by high-field-strength magnetic resonance imaging [72].

However, the size of antibodies is important and grafting them on small MNPs remains a critical issue for crossing the $\mathrm{BBB}$ and in view of envisaging their translation to the brain and clinical applications. Therefore, nanobodies, the monomeric variable domain of the antibody (12-15 kDa), have been set up to address these issues. Nowadays, numerous nanobodies selected by phage display and directed toward various amyloid deposits are available: B10AP against $\mathrm{A} \beta, \mathrm{Nb} 23$ against $\beta_{2}$-microglobulin, and cAb-HuL6 against lysozyme [73-77]. Indeed, nanobodies provide a lot of benefits: they are easy to produce, they are constituted by one single variable domain (VHH), they are less immunogenic and have a smaller size than antibodies while keeping their high affinity for amyloid deposits, and have a better chance to cross biological membranes [68,77]. Consequently, we have grafted the specific nanobody (B10AP) [78] to Gd(DOTA)PEG, and we showed that this complex displayed a high affinity for $A \beta$ fibers in vitro, with $K D$ values in the $10-n M$ range and specific $A \beta$ targeting on ex vivo AD mice model brain sections [16].

\subsection{MNPs for Other Amyloidosis Detection Tests}

Although much of this research field is focused on Alzheimer's Disease, some studies obviously show benefits for other medical applications. Pal et al. describe the detection of the $\beta_{2}$-microglobulin and ApoA1 amyloid proteins by polyclonal antibodies-MNPs in serum, with usefulness for the detection of ovarian cancer in an early stage [79]. The nanobody B10AP grafted with Gd(DOTA) shows detection towards amyloid fibers of islet amyloid polypeptide (IAPP) and fibers of transthyretin (TTR), which are involved in type 2 diabetes and polyneuropathy, respectively, and has great affinities with KD values in the 10-nM range in vitro [16]. Fluorescence imaging on slices of 
pancreas and stomach tissues of mice models using Gd(DOTA)-Cy5.5-B10AP has also shown selective targeting of IAPP and TTR aggregates [16].

\section{MNPs as In Vivo Diagnostic Probes}

The current technique for the detection and quantification of amyloidosis in vivo is positron emission tomography (PET) using radiolabeled probes presenting high and specific affinity for amyloid aggregates. In particular, brain amyloidosis can be staged with this technique and this new information can be combined with cognitive scores to confirm the diagnosis of AD and allow for accurate stratification of the disease for better patient management. Nowadays, several tracers, i.e., Amyvid ( ${ }^{18} \mathrm{~F}$-Florbetapir), Vizamyl ( ${ }^{18} \mathrm{~F}$-Flutemetamol), and Neuraceq ( ${ }^{18} \mathrm{~F}$-Florbetaben), have obtained Food Drug Administration approval as amyloid PET imaging probes and are currently used in the clinic [80-83]. PET can quantify the amyloid burden, but its low spatial resolution does not allow for visualization of single amyloid plaques. Positive scans using these probes do not establish a diagnosis of Alzheimer's disease, or other cognitive disorder; they increase the likelihood that memory impairment is caused by Alzheimer's disease. Furthermore, the lack of in vivo binding validation of these probes and the consequent deficiency in the understanding of their tissue binding and specificity are genuine concerns; neither compound is approved to quantify amyloid plaques in the brain. As a consequence, these tracers are an adjunct to other diagnostic evaluations. To improve specificity, a large number of other tracers are under clinical development. The literature contains highly divergent reports of the binding selectivity of these agents for the different forms of $A \beta$; for example, [ $\left.{ }^{11} \mathrm{C}\right] \mathrm{PIB}$ is often claimed to be able to bind strongly to fibrillar $\mathrm{A} \beta$ but only weakly to diffuse $\mathrm{A} \beta$ plaques. However, a number of recent studies have observed significant $\left[{ }^{11} \mathrm{C}\right] \mathrm{PIB}$ retention in correlation with the presence of both fibrillar and diffuse $A \beta$ plaques, leading authors to assert that this tracer cannot differentiate neuritic from diffuse amyloid plaques [84]. To conclude, none of the studies performed with these PET tracers mapped out A $\beta$ pathologies in sufficient detail to allow for quantitative regional cortical correlation of an amyloid imaging signal with an underlying pathology throughout the whole brain irrespective of the neurodegenerative disease. Magnetic resonance imaging (MRI) is also in fast development for medical diagnosis of neurodegenerative diseases in general and AD in particular. This technique produces two- and three-dimensional high-resolution images that do not involve ionizing radiation, which is required by radiochemistry. In the clinical routine, AD diagnosis is mainly done by observation of cerebral atrophy (medial temporal structures), which occurs at relatively late stages of the disease when cognitive decline has already started. More recently, functional alterations have also been investigated as early indirect and largely unspecific biomarkers using techniques such as task-based or resting state blood oxygen level dependent functional MRI.

Efforts are engaged in an earlier diagnosis of the disease, and MRI is currently being investigated as a unique tool to achieve in vivo amyloid plaque imaging [85]. Indeed, a large proportion of amyloid plaques stores iron in their cores and therefore modifies the MRI signal in their surroundings, giving hypo-intense spots (a susceptibility effect) on $\mathrm{T}_{2}$ and $\mathrm{T}_{2}{ }^{*}$ images [86-88]. The main problem that remains is that the required acquisition time for reaching a sufficiently high resolution $(100 \mu \mathrm{m})$ to detect these spots is much too long $(>2 \mathrm{~h}$ ) for applying the technique to weak patients in a clinical routine even at a high magnetic field. However, this can be achieved in small animal models at a very high magnetic field with high performance sensors and long acquisition times allowing for very high resolution $(<100 \mu \mathrm{m})$ [89]. Even under such conditions, this technique works well ex vivo after exsanguino-perfusion of the brains [90] while it remains difficult to perform in vivo as shown in Figure 3. This is because of the relatively lower spatial resolution achieved in vivo in reasonable scan times and also because of the competition between $\mathrm{T}_{2}$ hypo-signals originating from blood iron and iron contained in plaques. 


\section{In vivo acquisition}

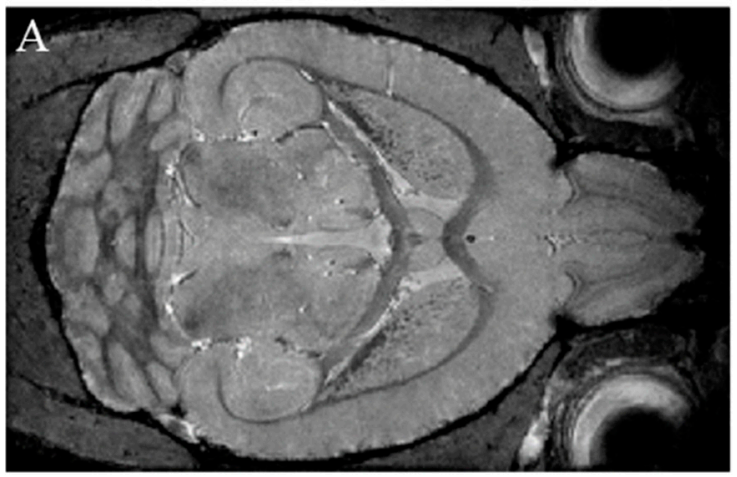

\section{Ex vivo acquisition}

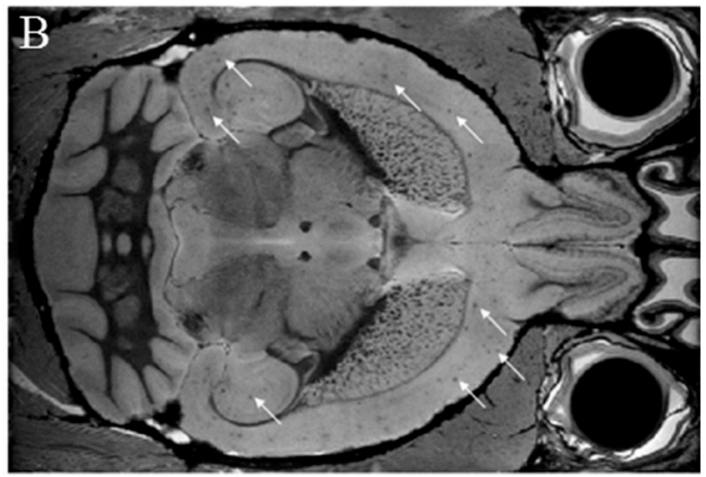

Figure 3. Alzheimer's disease (AD) mouse brain (12 months old) $\mathrm{T}_{2}{ }^{*}$-weighted MRI images acquired at $7 \mathrm{~T}$ without a contrast agent. No direct amyloid plaque detection is possible in vivo (A) while the absence of blood and the highest resolution make amyloid plaques clearly visible ex vivo (B). Three-dimensional (3D) gradient-echo sequences: In vivo parameters: echo time $4 \mathrm{~ms}$, repetition time $90 \mathrm{~ms}$, echo spacing $3 \mathrm{~ms}$, resolution $60 \times 60 \times 60 \mu \mathrm{m}^{3}$, matrix size $280 \times 180 \times 120$, number of echoes 8, no average, acquisition time $32 \mathrm{~min}$; Ex vivo parameters: echo time $4 \mathrm{~ms}$, repetition time 90 ms, echo spacing $4.75 \mathrm{~ms}$, resolution $40 \times 40 \times 40 \mu^{3}$, matrix size $400 \times 270 \times 180$, number of echoes 8,12 averages, acquisition time of $12 \mathrm{~h}$.

Thus, the development of contrast agents is crucial for distinguishing AD tissue and improving amyloid imaging. Some authors have tested the possibility of using untargeted gadolinium-based MNPs to enhance the contrast between the amyloid plaques and the surrounding brain tissue, a technique known as "passive staining" [91]. It consists in delivering Gd-based contrast agents (Gd-DOTA, Dotarem ${ }^{\circledR}$ ) to the whole brain by intra-cerebro-ventricular injections in vivo or by a bath in a contrast agent solution for fixed brains. However, the clinical translation of this approach seems difficult for several reasons: in vivo homogeneous delivery of Gd chelates into the brain by ventricular injection is not possible in patients and the contrast-to-noise ratio remains low under in vivo imaging conditions, making amyloid plaques difficult to detect from blood vessels as the blood also contains iron.

In order to increase the specificity and contrast-to-noise ratio of amyloid detection, targeted MNPs have been developed and validated for their capability to bind amyloid aggregates. The availability of MRI amyloid tracers can provide an earlier diagnosis of neurodegenerative diseases but also a quantitative monitoring of treatments. Two main types of MNPs are currently used to detect amyloid deposits: superparamagnetic contrast agents and paramagnetic contrast agents. The first category, i.e., iron oxide NPs, such as USPIO, MION, and SPION, acts as $\mathrm{T}_{2}$ contrast agents that decrease locally the image signal by shortening $\mathrm{T}_{2}$, while the second category, i.e., Gd-derived NPs, acts as $\mathrm{T}_{1}$ contrast agents that enhance locally the image signal by shortening $\mathrm{T}_{1}$. In the case of iron oxide NPs, MNPs have been grafted with $A \beta$ peptide moieties, such as $A \beta_{1-40}$ or $A \beta_{1-42}, K 6 A \beta_{1-30}$, or antibody fragments, such as anti-A $\beta_{42}-\mathrm{F}\left(\mathrm{ab}^{\prime}\right) 2$. Peptides target amyloid plaques, and MNP properties show a significant decrease in apparent transverse relaxation $\left(\mathrm{T}_{2}{ }^{*}\right)$ values [62,92,93]. However, in these studies a toxicity was reported, which was likely due to A $\beta$ peptides grafted on MNPs or to the immunogenicity of targeting antibodies, which can constitute a limit for their clinical translation. This important aspect needs to be taken into account from the beginning of the development of these targeted MNPs. A large variety of SPIONs has been designed for MRI because they present a certain efficiency to cross the BBB and act as promising in vivo contrast agents [92-99]. On AD mice models, Anti-A $\beta$ PP antibodies-coated SPIONS doubled the number of MRI-visible plaques with suggested spontaneous crossing of the BBB [94]. Poduslo et al. shows specific dark spots on $\mathrm{T}_{2}{ }^{*}$-weighted images located in cortical arterioles thanks to monoclonal antibody IgG4.1-targeted MIONS [72]. Some other iron oxide NPs grafted with peptides having a hydrophobic character 
and selected through a library of small peptides, termed USPIO-PHO, remain a high contrast tool for transgenic mice using $\mathrm{T}_{2}$-weighted MRI sequences [86-98]. MNPs grafted with the polyphenolic curcumin, and stabilized by an amphiphilic copolymer, have shown great detection of amyloid deposits in ex vivo brain scanned by $\mathrm{T}_{2}{ }^{*}$-weighted MRI [39]. Similar work with the anti-A $\beta$ monoclonal antibody BAM10 grafted to $\gamma-\mathrm{Fe}_{2} \mathrm{O}_{3}$ nanoparticles shows that they are able to interact with $\mathrm{A} \beta_{40}$ fibrils and to target $A \beta$ plaques ex vivo in rat brain detected by MRI imaging [99]. These SPION-based MNPs present encouraging results in animal models but their utilization in humans remains limited owing to many drawbacks [100]. Mainly, the dark spots due to the blood vessels are often indistinguishable from the ones due to SPION-targeted amyloid aggregates. Therefore, proper amyloid diagnosis still needs further ex vivo confirmation [101]. As an example, using USPIO-PEG-A $\beta_{1-42}$ [92], authors reported hypo-signals similar to a compound targeting amyloid in wild-type (WT) mice, emphasizing the difficulty in distinguishing marked amyloid plaques from blood vessels on $\mathrm{T}_{2}{ }^{*}$ images. To avoid confusion with blood vessels, a contrast agent affecting $\mathrm{T}_{1}$ relaxation might be useful, as it would induce hyper intense signals that are easily distinguishable from blood vessels.

Manganese oxide NPs grafted with anti-A $\beta_{1-40}$ antibodies show hyper-enhanced spots in the frontal cortex area with $\mathrm{T}_{1}$-weighted images [95]. Manganese ions shorten the $\mathrm{T}_{1}$ relaxation times of surrounding protons and were proposed as in vivo paramagnetic probes that are easily distinguishable from blood hypo-intense signals. However, this family of MNPs is restricted to animal studies since manganese ions are toxic in the brain.

Alternatively, Gadolinium chelates are the most widely used MRI contrast agents, with nine products already approved for clinical applications [102]. $\mathrm{Gd}^{3+}$ ions also reduce the $\mathrm{T}_{1}$ relaxation time of surrounding protons. Some, i.e., $A G u I X^{\circledR}$, show high $r_{1}$ relaxivity due to their high paramagnetism [103], stability, and clearance from the body [104]. Regarding AD and cerebral amyloid angiopathy, the combination of Gd-based NPs with several targeting molecules, i.e., PIB, polyphenols, peptides, and antibodies, remains the common strategy [98,104-108]. Most of these works attempt to prove the in vivo concept, but the concept also needs ex vivo confirmation. Thus, in AD mice models, a putrescine-gadolinium-A $\beta$ probe (PUT-Gd-A $\beta$ [109]) is able to improve the contrast of amyloid

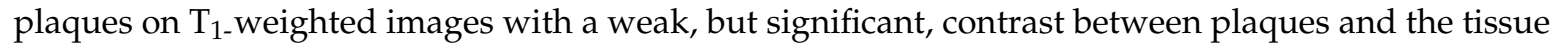
in vivo. Gd(DO3A)-PIB shows a specific recognition of $A \beta$ plaques [61], as do Gd(DTPA) grafted with $A \beta$ peptide [67] or curcumin [106] and anti-A $\beta$ antibody IgG4.1 vectorized on Gd(DOTA) [107]. Likewise, AGuIX NPs were grafted with PIB probes (Gd(DOTA)PEG-PIB) for the diagnosis of amyloidoses. These MNPs are made of a polysiloxane network surrounded by several DOTAGA $\left(\mathrm{Gd}^{3+}\right)$ chelates [108,109]. AGuIX nanoparticles have a hydrodynamic diameter smaller than $5 \mathrm{~nm}$ and have been already efficiently used for MRI imaging and radio-sensitization [110]. Free ligands are available at the surface of AGuIX and can be used to chelate radioisotopes (e.g., ${ }^{68} \mathrm{Ga}^{3+}$ or ${ }^{111} \mathrm{In}^{3+}$ ) in order to perform PET or Single-photon emission computed tomography (SPECT) imaging [111,112]. Moreover, the covalent grafting of a near-infrared dye, such as cyanine5.5 (Cy5.5), is also achievable for optical imaging [113]. Recently, we showed that AGuIX can be functionalized with specific A $\beta$ peptides to selectively target and image A $\beta$-amyloid fibrils [67]. Similarly, these nanoparticles grafted with PIB, Gd(DOTA)PEG-PIB, showed effective and specific interaction with amyloid plaques in vitro. Therefore, they were injected in vivo for evaluating MRI amyloid imaging and targeting (Figure 4). As those compounds present moderate efficiency to cross naturally the BBB, we have mechanically increased its permeability using an ultrasound-induced BBB opening (see Supplementary Materials). In this context, a low-intensity focused ultrasound are a safe and reproducible technique to transiently open the BBB for drug delivery [114-116]. Microbubbles, intravenously injected in the blood, will oscillate under the action of the ultrasound and mechanically stress the endothelial cells of the BBB, which will contract and loosen their tight-junctions. This opening lasts few hours and allows for particles up to $60 \mathrm{~nm}$ (hydrodynamic diameter) to cross the BBB [117]. We have used this ultrasound technology to target amyloid plaques in vivo with PIB-grafted Gd(DOTA)PEG, which are small MNPs $(<5 \mathrm{~nm})$, to increase their delivery ((1) in Figure 4). The MRI images in Figure 4(3) show $\mathrm{T}_{1}$-weighted 
images pre- and post-BBB opening along with injection of Gd(DOTA)PEG-PIB. Ultrasound were shot, by a piezoelectric transducer, in the brain of a double transgenic mouse model of Alzheimer's disease (APP/PS1 $\triangle \mathrm{E} 9$ ) [118]. We used a global sonication of the brain to cover a large volume as evidenced by the signal enhancement in the sonicated area on the post-ultrasound image compared to the non-sonicated prefrontal cortex $(\sim+20 \%)$. These results suggest that the ultrasound protocol was efficient in opening the BBB and allowed the MNPs to reach the brain parenchyma.
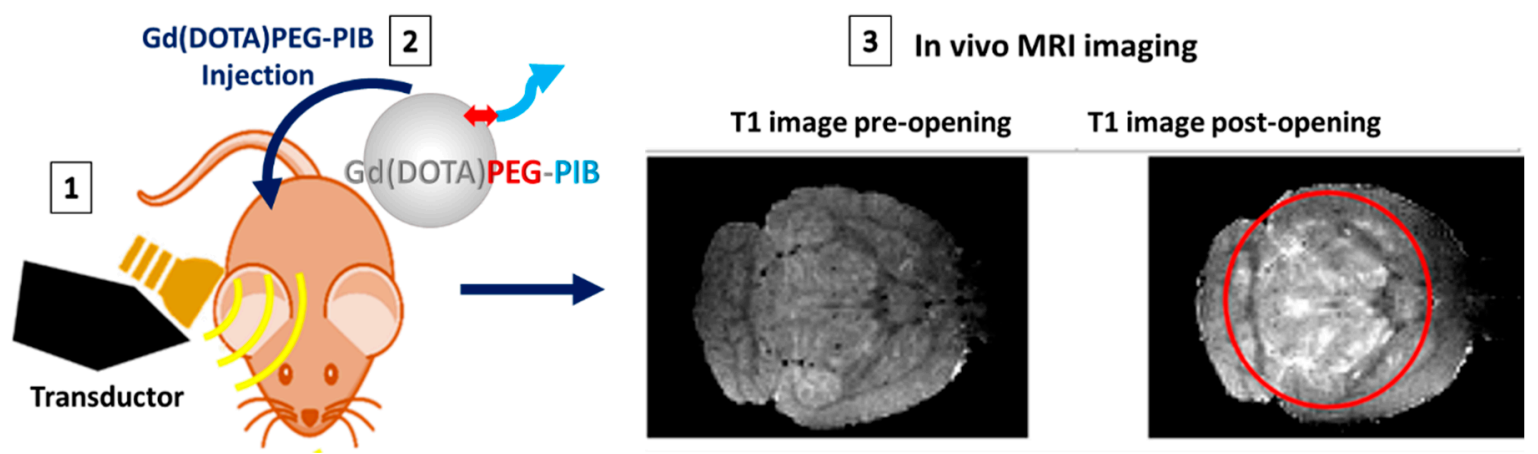

Figure 4. Ultrasound technology was applied via a transductor (1) on the brain of a transgenic mouse model of Alzheimer's disease (APP/PS1 $\triangle \mathrm{E} 9$ ) in order to increase the delivery of Gd(DOTA) grafted with PIB (Gd(DOTA)PEG-PIB) previously intravenously injected (2). The method consists of sonicating a large part of the brain, allowing for BBB disruption with a global intensity and on a high volume of brain, as observed in the post-ultrasound image compared to the prefrontal cortex ( +20\%): MRI images show $\mathrm{T}_{1}$-weighted images pre- and post-BBB opening along with injection of Gd(DOTA)PEG-PIB (3). The MNPs signal appears as a hypersignal affecting the $\mathrm{T}_{1}$ relaxation time.

Thereafter, the ability of nanoparticles to target amyloid plaques in vivo was assessed by immunohistology (Figure 5; see method in Supplementary Materials). Gd(DOTA)PEG-PIB has been found in brain tissue, mainly in the thalamus nuclei (ventral, lateral, and posterior lateral), geniculate nuclei, amygdaloid (basolateral, post-lateral, post-medium) nuclei, and piriform and enthorinal cortex (Figure 5A). Some nanoparticles appear to be associated with or close to the amyloid aggregates (Figure 5B-F), suggesting the need to follow the behavior of the MNPs at different times after injection to distinguish specific from nonspecific targeting. Control nanoparticles (without the PIB ligand) also cross the BBB after ultrasound and diffused into the tissue (Figure 5G). However, no colocalization was evidenced between amyloid plaques and Gd(DOTA)PEG. Finally, the nanoparticles injected into mice whose BBB was not opened by the ultrasound technique remained in the cerebral vascular area (Figure $5 \mathrm{H}$ ). 

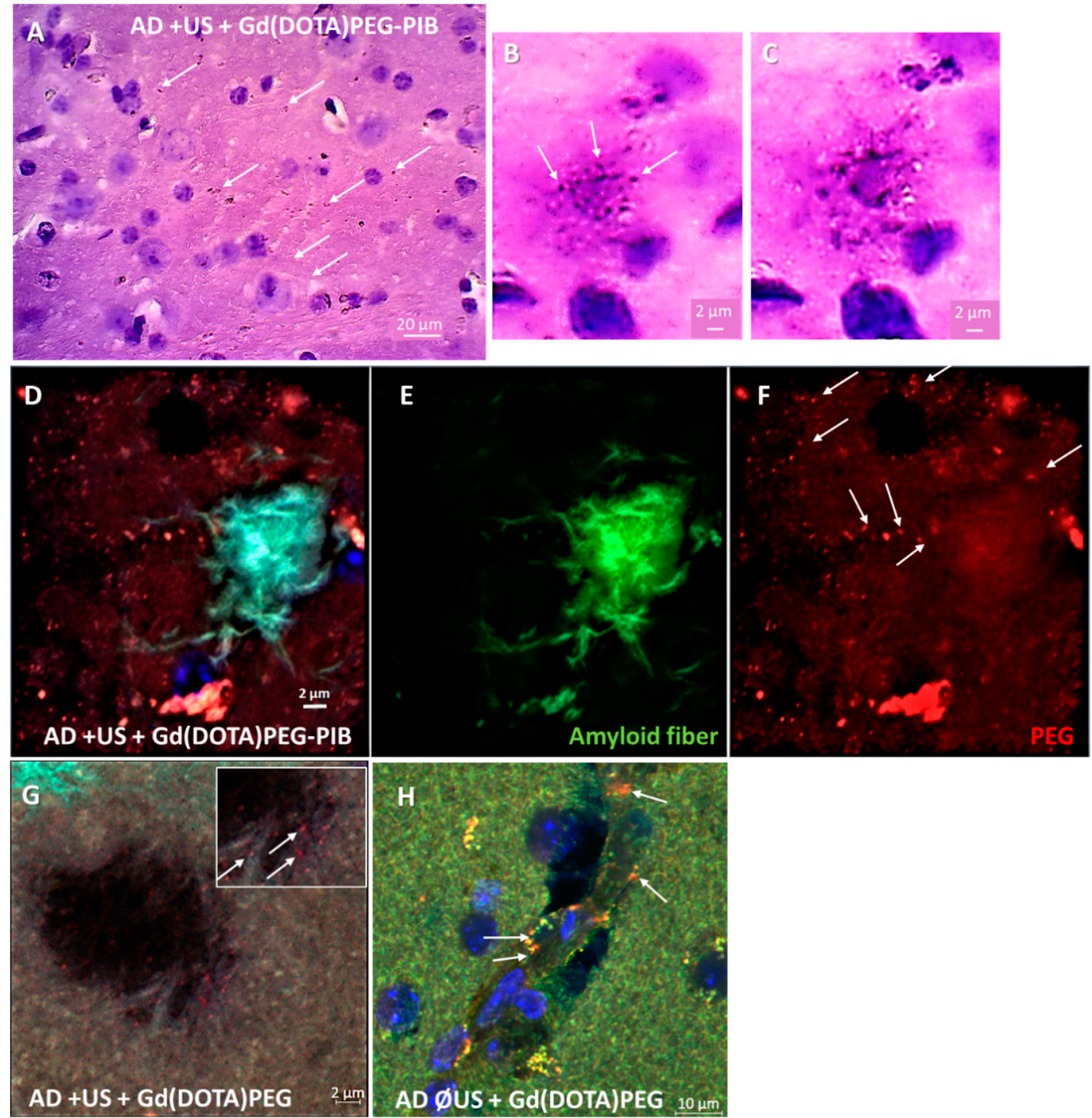

Figure 5. Immunohistological pictures of Gd(DOTA)PEG-PIB delivery inside cerebral tissue after blood-brain barrier (BBB) opening by ultrasound. (A-C) The images revealed the diffusion of MNPs into the brain using an antibody directed against the spacer PEG integrated in MNPs (brown spots) (A). Some of the Gd(DOTA)PEG-PIB were located in the vicinity of amyloid plaques (hematoxylin-eosin counterstaining) (B,C). (D-F) Confocal microscopy observations confirmed a close colocalization (D) between amyloid fibers ((E): thioflavin S staining (green)) and Gd(DOTA)PEG-PIB ((F): anti-PEG antibody revealed by secondary conjugated antibody Alexa-594 (red)). (G,H) For control, other AD mice were injected with MNPs without the amyloid-targeting PIB with $(\mathbf{G})$ or without (H) prior ultrasound opening of the BBB; MNPs diffuse into the brain, but no specific accumulation around amyloid aggregates was observed $(\mathbf{G})$, suggesting they remained localized in the vessel $(\mathbf{H})$.

\section{Conclusions}

Functionalized or free MNPs remain accurate and versatile tools to better understand amyloidosis, especially concerning neurodegenerative diseases. Nowadays, they have become essential objects in the search for new medical approaches to amyloid deposits in fundamental and applied research. The ability to detect them by MRI remains a major advantage thanks to their intrinsic magnetic properties. Efforts should be made to ensure the safety of their use [119] in applications ranging from proteomics and genomics screening [120] to pathophysiology assessments. In this context, a growing number of MNPs is used nowadays in the research field, and careful consideration should be given 
in terms of their toxicity for human health and for the environment. Another potential limitation of this MRI-based strategy for repeated chronic injections in patients is the potential toxic accumulation of metals in the brain. Indeed, the clearance mechanisms of iron and gadolinium from the brain are still poorly known and this topic requires extensive study. Therefore, thanks to advances in bioengineering, the production of biocompatible MNPs with high medical relevance appears to be one of the most promising ways to diagnose and treat various amyloidosis associated with a wide range of diseases.

Supplementary Materials: Materials and Methods are available online at http:/ /www.mdpi.com/2079-4991/ 8/9/740/s1.

Author Contributions: Conceptualization, B.L. and C.M.; Methodology, J.P., M.G., B.L. and C.M.; Investigation, J.P., M.G., B.L. and C.M.; Writing-Original Draft Preparation, J.P. and C.M.; Writing-Review \& Editing, J.P., M.G., B.L., S.M., F.L., O.T., V.F. and C.M.; Funding Acquisition, B.L., V.F. and C.M.

Funding: This research was funded by Euronanomed ENMII JTC2012 (project 2011-ERA-002-01-Dia-Amyl) and the French National Research Agency (ANR): ANR-12-RPIB Multimage. J.P. has a grant from the "fondation pour la Recherche Médicale" (grant \#: FRM DBS2013112844). M.G. has a grant from a CEA Irtélis fellowship. The experimental results are supported by the CEA "Technologies for Health" transversal program.

Acknowledgments: The authors wish to thank Erwan Selingue for his assistance in the animal experiments.

Conflicts of Interest: The authors declare no conflict of interest. F.L. and O.T. have to disclose the patent WO2011/135101. This patent protects the AGuIX ${ }^{\circledR}$ NPs described in this publication. F.L. and O.T. are employees of NH TherAguix that is developing the AGuIX ${ }^{\circledR}$ NPs and possess shares in this company.

\section{Abbreviations}

MNPs magnetic nanoparticles

PIB Pittsburgh compound B

AD Alzheimer's Disease

PD Parkinson's Disease

$\mathrm{A} \beta \quad$ amyloid beta protein

$\alpha$-syn $\quad \alpha$-synuclein

$\operatorname{PrP} \quad$ prion protein

$\mathrm{PrPc} \quad$ cellular prion protein

IAPP islet amyloid polypeptide

TTR transthyretin

BBB blood-brain barrier

MRI magnetic resonance imaging

PET positron emission tomography

PEG polyethylene glycol

USPIO ultrasmall paramagnetic iron oxide

MION magnetic iron oxide nanoparticles

SPION supramagnetic iron oxide nanoparticles

ThT Thioflavin T

i.v. intravenous administration

\section{References}

1. Klein, W.L.; Krafft, G.A.; Finch, C.E. Targeting small A $\beta$ oligomers: The solution to an Alzheimer's disease conundrum? Trends Neurosci. 2001, 24, 219-224. [CrossRef]

2. Sipe, J.D.; Benson, M.D.; Buxbaum, J.N.; Ikeda, S.; Merlini, G.; Saraiva, M.J.M.; Westermark, P. Amyloid fibril proteins and amyloidosis: Chemical identification and clinical classification International Society of Amyloidosis 2016 Nomenclature Guidelines. Amyloid 2016, 23, 209-213. [CrossRef] [PubMed]

3. Floege, J.; Ehlerding, G. Beta-2-Microglobulin-Associated Amyloidosis. Nephron 1996, 72, 9-26. [CrossRef] [PubMed]

4. Reches, M.; Porat, Y.; Gazit, E. Amyloid Fibril Formation by Pentapeptide and Tetrapeptide Fragments of Human Calcitonin. J. Biol. Chem. 2002, 277, 35475-35480. [CrossRef] [PubMed] 
5. Haataja, L.; Gurlo, T.; Huang, C.J.; Butler, P.C. Islet Amyloid in Type 2 Diabetes, and the Toxic Oligomer Hypothesis. Endocr. Rev. 2008, 29, 303-316. [CrossRef] [PubMed]

6. Hatters, D.M.; Howlett, G.J. The structural basis for amyloid formation by plasma apolipoproteins: A review. Eur. Biophys. J. 2002, 31, 2-8. [CrossRef] [PubMed]

7. Teoh, C.L.; Griffin, M.D.W.; Howlett, G.J. Apolipoproteins and amyloid fibril formation in atherosclerosis. Protein Cell 2011, 2, 116-127. [CrossRef] [PubMed]

8. Soto, C. Unfolding the role of protein misfolding in neurodegenerative diseases. Nat. Rev. Neurosci. 2003, 4, 49-60. [CrossRef] [PubMed]

9. World Alzheimer Report 2016 -Improving Healthcare for People Living with Dementia: Coverage, Quality and Costs Now and in the Future; Alzheimer's Disease International (ADI): London, UK, 2016; 140p.

10. Pardridge, W.M. The blood-brain barrier: Bottleneck in brain drug development. Neurotherapeutics 2005, 2, 3-14. [CrossRef] [PubMed]

11. Parveen, S.; Misra, R.; Sahoo, S.K. Nanoparticles: A boon to drug delivery, therapeutics, diagnostics and imaging. Nanomed. Nanotechnol. Boil. Med. 2012, 8, 147-166. [CrossRef] [PubMed]

12. Kouassi, G.K.; Irudayaraj, J. Magnetic and Gold-Coated Magnetic Nanoparticles as a DNA Sensor. Anal. Chem. 2006, 78, 3234-3241. [CrossRef] [PubMed]

13. Zaman, M.; Ahmad, E.; Qadeer, A.; Rabbani, G.; Khan, R.H. Nanoparticles in relation to peptide and protein aggregation. Int. J. Nanomed. 2014, 9, 899-912. [CrossRef]

14. Shaalan, M.; Saleh, M.; El-Mahdy, M.; El-Matbouli, M. Recent progress in applications of nanoparticles in fish medicine: A review. Nanomed. Nanotechnol. Boil. Med. 2016, 12, 701-710. [CrossRef] [PubMed]

15. Li, Z.; Wang, G.; Shen, Y.; Guo, N.; Ma, N. Circulating Tumor Cells: DNA-Templated Magnetic Nanoparticle-Quantum Dot Polymers for Ultrasensitive Capture and Detection of Circulating Tumor Cells. Adv. Funct. Mater. 2018, 28, 1870089. [CrossRef]

16. Pansieri, J.; Plissonneau, M.; Stransky-Heilkron, N.; Dumoulin, M.; Heinrich-Balard, L.; Rivory, P.; Morfin, J.-F.; Toth, E.; Saraiva, M.J.; Allémann, E.; et al. Multimodal imaging Gd-nanoparticles functionalized with Pittsburgh compound B or a nanobody for amyloid plaques targeting. Nanomedicine 2017, 12, 1675-1687. [CrossRef] [PubMed]

17. Zhou, J.; Gan, N.; Li, T.; Zhou, H.; Li, X.; Cao, Y.; Wang, L.; Sang, W.; Hu, F. Ultratrace detection of C-reactive protein by a piezoelectric immunosensor based on $\mathrm{Fe}_{3} \mathrm{O}_{4} @ \mathrm{SiO}_{2}$ magnetic capture nanoprobes and HRP-antibody co-immobilized nano gold as signal tags. Sens. Actuators B Chem. 2013, 178, 494-500. [CrossRef]

18. Zhou, H.; Gan, N.; Li, T.; Cao, Y.; Zeng, S.; Zheng, L.; GuO, Z. The sandwich-type electroluminescence immunosensor for a-fetoprotein based on enrichment by $\mathrm{Fe}_{3} \mathrm{O}_{4}$ - $\mathrm{Au}$ magnetic nano probes and signal amplification by CdS-Au composite nanoparticles labeled anti-AFP. Anal. Chim. Acta 2012, 746, 107-113. [CrossRef] [PubMed]

19. Gan, N.; Yang, X.; Xie, D.; Wu, Y.; Wen, W. A disposable organophosphorus pesticides enzyme biosensor based on magnetic composite nano-particles modified screen printed carbon electrode. Sensors 2010, 10, 625-638. [CrossRef] [PubMed]

20. Zamfir, L.G.; Geana, I.; Bourigua, S.; Rotariu, L.; Bala, C.; Errachid, A.; Jaffrezic-Renault, N. Highly sensitive label-free immunosensor for ochratoxin A based on functionalized magnetic nanoparticles and EIS/SPR detection. Sens. Actuators B Chem. 2011, 159, 178-184. [CrossRef]

21. Agrawal, S.; Paknikar, K.; Bodas, D. Development of immunosensor using magnetic nanoparticles and circular microchannels in PDMS. Microelectron. Eng. 2014, 115, 66-69. [CrossRef]

22. Pankhurst, Q.A.; Connolly, J.; Jones, S.K.; Dobson, J. Applications of magnetic nanoparticles in biomedicine. J. Phys. D Appl. Phys. 2003, 36, R167. [CrossRef]

23. Cui, Z.; Lockman, P.R.; Atwood, C.S.; Hsu, C.-H.; Gupte, A.; Allen, D.D.; Mumper, R.J. Novel d-penicillamine carrying nanoparticles for metal chelation therapy in Alzheimer's and other CNS diseases. Eur. J. Pharm. Biopharm. 2005, 59, 263-272. [CrossRef] [PubMed]

24. Bobo, D.; Robinson, K.J.; Islam, J.; Thurecht, K.J.; Corrie, S.R. Nanoparticle-Based Medicines: A Review of FDA-Approved Materials and Clinical Trials to Date. Pharm. Res. 2016, 33, 2373-2387. [CrossRef] [PubMed]

25. Pedram, M.; Shamloo, A.; Alasty, A.; Ghafar-Zadeh, E.; Pedram, M.Z.; Shamloo, A.; Alasty, A.; Ghafar-Zadeh, E. Optimal Magnetic Field for Crossing Super-Para-Magnetic Nanoparticles through the Brain Blood Barrier: A Computational Approach. Biosensors 2016, 6, 25. [CrossRef] [PubMed] 
26. Li, X.; Wei, J.; Aifantis, K.E.; Fan, Y.; Feng, Q.; Cui, F.-Z.; Watari, F. Current investigations into magnetic nanoparticles for biomedical applications. J. Biomed. Mater. Res. Part A 2016, 104, 1285-1296. [CrossRef] [PubMed]

27. Long, N.V.; Yang, Y.; Teranishi, T.; Thi, C.M.; Cao, Y.; Nogami, M. Biomedical Applications of Advanced Multifunctional Magnetic Nanoparticles. J. Nanoscie. Nanotechn. 2015, 15, 10091-10107. [CrossRef]

28. Blanco-Andujar, C.; Walter, A.; Cotin, G.; Bordeianu, C.; Mertz, D.; Felder-Flesch, D.; Begin-Colin, S. Design of iron oxide-based nanoparticles for MRI and magnetic hyperthermia. Nanomedicine 2016, 11, 1889-1910. [CrossRef] [PubMed]

29. Shubayev, V.I.; Pisanic, T.R.; Jin, S. Magnetic nanoparticles for theragnostics. Adv. Drug Deliv. Rev. 2009, 61,467-477. [CrossRef] [PubMed]

30. Gupta, A.K.; Gupta, M. Synthesis and surface engineering of iron oxide nanoparticles for biomedical applications. Biomaterials 2005, 26, 3995-4021. [CrossRef] [PubMed]

31. Ferrone, F.A.; Hofrichter, J.; Eaton, W.A. Kinetics of sickle hemoglobin polymerization: II. A double nucleation mechanism. J. Mol. Boil. 1985, 183, 611-631. [CrossRef]

32. O'Nuallain, B.; Williams, A.D.; Westermark, P.; Wetzel, R. Seeding Specificity in Amyloid Growth Induced by Heterologous Fibrils. J. Biol. Chem. 2004, 279, 17490-17499. [CrossRef] [PubMed]

33. Kumar, S.; Udgaonkar, J.B. Mechanisms of amyloid fibril formation by proteins. Curr. Sci. 2010, 98, 639-656.

34. Kell, D.B.; Pretorius, E. Proteins behaving badly. Substoichiometric molecular control and amplification of the initiation and nature of amyloid fibril formation: Lessons from and for blood clotting. Prog. Biophys. Mol. Boil. 2017, 123, 16-41. [CrossRef] [PubMed]

35. Meisl, G.; Samuel, L.R.; Cohen, A.I.; Pfammatter, M.; Sari, A.; Hellstrand, E.; Buell, A.K.; Aguzzi, A.; Linse, S.; Vendruscolo, M.; et al. Scaling behaviour and rate-determining steps in filamentous self-assembly. Chem. Sci. 2017, 8, 7087.

36. Pansieri, J.; Halim, M.A.; Vendrely, C.; Dumoulin, M.; Legrand, F.; Moulin Sallanon, M.; Chierici, S.; Denti, S.; Dagany, X.; Dugourd, P.; et al. Mass and charge distributions of amyloid fibers involved in neurodegenerative diseases: Mapping heterogeneity and polymorphism. Chem. Sci. 2018. [CrossRef] [PubMed]

37. Chiti, F.; Dobson, C.M. Protein Misfolding, Amyloid Formation, and Human Disease: A Summary of Progress Over the Last Decade. Annu. Rev. Biochem. 2017, 86, 27-68. [CrossRef] [PubMed]

38. Shan, L. Superparamagnetic iron oxide nanoparticles (SPION) stabilized by alginate. In Molecular Imaging and Contrast Agent Database (MICAD); National Center for Biotechnology Information (US): Bethesda, MD, USA, 2004.

39. Cheng, K.K.; Chan, P.S.; Fan, S.; Kwan, S.M.; Yeung, K.L.; Wáng, Y.-X.J.; Chow, A.H.L.; Wu, E.X.; Baum, L. Curcumin-conjugated magnetic nanoparticles for detecting amyloid plaques in Alzheimer's disease mice using magnetic resonance imaging (MRI). Biomaterials 2015, 44, 155-172. [CrossRef] [PubMed]

40. Mirsadeghi, S.; Shanehsazzadeh, S.; Atyabi, F.; Dinarvand, R. Effect of PEGylated superparamagnetic iron oxide nanoparticles (SPIONs) under magnetic field on amyloid beta fibrillation process. Mater. Sci. Eng. C 2016, 59, 390-397. [CrossRef] [PubMed]

41. Mahmoudi, M.; Quinlan-Pluck, F.; Monopoli, M.P.; Sheibani, S.; Vali, H.; Dawson, K.A.; Lynch, I. Influence of the Physiochemical Properties of Superparamagnetic Iron Oxide Nanoparticles on Amyloid $\beta$ Protein Fibrillation in Solution. ACS Chem. Neurosci. 2013, 4, 475-485. [CrossRef] [PubMed]

42. Naik, A.; Kambli, P.; Borana, M.; Mohanpuria, N.; Ahmad, B.; Kelkar-Mane, V.; Ladiwala, U. Attenuation of lysozyme amyloid cytotoxicity by SPION-mediated modulation of amyloid aggregation. Int. J. Boil. Macromol. 2015, 74, 439-446. [CrossRef] [PubMed]

43. Wang, P.; Kouyoumdjian, H.; Zhu, D.C.; Huang, X. Heparin nanoparticles for $\beta$ amyloid binding and mitigation of $\beta$ amyloid associated cytotoxicity. Carbohydr. Res. 2015, 405, 110-114. [CrossRef] [PubMed]

44. Zhang, M.; Mao, X.; Yu, Y.; Wang, C.-X.; Yang, Y.-L.; Wang, C. Nanomaterials for Reducing Amyloid Cytotoxicity. Adv. Mater. 2013, 25, 3780-3801. [CrossRef] [PubMed]

45. Mahmoudi, M.; Shokrgozar, M.A.; Sardari, S.; Moghadam, M.K.; Vali, H.; Laurent, S.; Stroeve, P. Irreversible changes in protein conformation due to interaction with superparamagnetic iron oxide nanoparticles. Nanoscale 2011, 3, 1127-1138. [CrossRef] [PubMed]

46. Amani, S.; Naeem, A. Transition of transferrin from native to fibrillar state: An implication for amyloid-linked diseases. Biochem. Eng. J. 2014, 91, 120-128. [CrossRef] 
47. Wu, W.; Sun, X.; Yu, Y.; Hu, J.; Zhao, L.; Liu, Q.; Zhao, Y.; Li, Y. TiO 2 nanoparticles promote $\beta$-amyloid fibrillation in vitro. Biochem. Biophys. Res. Commun. 2008, 373, 315-318. [CrossRef] [PubMed]

48. Elbassal, E.A.; Morris, C.; Kent, T.W.; Lantz, R.; Ojha, B.; Wojcikiewicz, E.P.; Du, D. Gold Nanoparticles as a Probe for Amyloid- $\beta$ Oligomer and Amyloid Formation. J. Phys. Chem. C 2017, 121, 20007-20015. [CrossRef] [PubMed]

49. Benilova, I.; Karran, E.; Strooper, B.D. The toxic A $\beta$ oligomer and Alzheimer's disease: An emperor in need of clothes. Nat. Neurosci. 2012, 15, 349-357. [CrossRef] [PubMed]

50. Kayed, R.; Glabe, C.G. Conformation-Dependent Anti-Amyloid Oligomer Antibodies. Methods Enzymol. 2006, 413, 326-344. [PubMed]

51. Hsieh, S.; Chang, C.; Chou, H. Gold nanoparticles as amyloid-like fibrillogenesis inhibitors. Colloids Surf. B Biointerfaces 2013, 112, 525-529. [CrossRef] [PubMed]

52. Dubey, K.; Anand, B.G.; Badhwar, R.; Bagler, G.; Navya, P.N.; Daima, H.K.; Kar, K. Tyrosineand tryptophan-coated gold nanoparticles inhibit amyloid aggregation of insulin. Amino Acids 2015, 47, 2551-2560. [CrossRef] [PubMed]

53. Álvarez, Y.D.; Fauerbach, J.A.; Pellegrotti, J.V.; Jovin, T.M.; Jares-Erijman, E.A.; Stefani, F.D. Influence of Gold Nanoparticles on the Kinetics of $\alpha$-Synuclein Aggregation. Nano Lett. 2013, 13, 6156-6163. [CrossRef] [PubMed]

54. Sen, S.; Konar, S.; Pathak, A.; Dasgupta, S.; DasGupta, S. Effect of Functionalized Magnetic MnFe2O4 Nanoparticles on Fibrillation of Human Serum Albumin. J. Phys. Chem. B 2014, 118, 11667-11676. [CrossRef] [PubMed]

55. Skaat, H.; Margel, S. Newly Designed Magnetic and Non-Magnetic Nanoparticles for Potential Diagnostics and Therapy of Alzheimer's Disease. J. Biotechnol. Biomater. 2013, 3, 1-8. [CrossRef]

56. Wang, J.-X.; Zhuo, Y.; Zhou, Y.; Wang, H.-J.; Yuan, R.; Chai, Y.-Q. Ceria Doped Zinc Oxide Nanoflowers Enhanced Luminol-Based Electrochemiluminescence Immunosensor for Amyloid- $\beta$ Detection. ACS Appl. Mater. Interfaces 2016, 8, 12968-12975. [CrossRef] [PubMed]

57. Tsolakis, A.C.; Halevas, E.; Vouroutzis, N.; Koliakos, G.G.; Salifoglou, A.; Litsardakis, G. Magnetic Fluorescent Nanoparticles Binding to Amyloid-Beta Peptide: Silica-Coated, Thioflavin-T Functionalized Iron Oxide. IEEE Trans. Magn. 2017, 53, 1-4. [CrossRef]

58. Martins, A.F.; Morfin, J.-F.; Geraldes, C.F.G.C.; Tóth, É. Gd3+ complexes conjugated to Pittsburgh compound B: Potential MRI markers of $\beta$-amyloid plaques. J. Biol. Inorg. Chem. 2014, 19, 281-295. [CrossRef] [PubMed]

59. Rabinovici, G.D.; Furst, A.J.; O’Neil, J.P.; Racine, C.A.; Mormino, E.C.; Baker, S.L.; Chetty, S.; Patel, P.; Pagliaro, T.A.; Klunk, W.E.; et al. ${ }^{11}$ C-PIB PET imaging in Alzheimer disease and frontotemporal lobar degeneration. Neurology 2007, 68, 1205. [CrossRef] [PubMed]

60. Villemagne, V.L.; Pike, K.E.; Chételat, G.; Ellis, K.A.; Mulligan, R.S.; Bourgeat, P.; Ackermann, U.; Jones, G.; Szoeke, C.; Salvado, O.; et al. Longitudinal assessment of A $\beta$ and cognition in aging and Alzheimer disease. Ann. Neurol. 2011, 69, 181-192. [CrossRef] [PubMed]

61. Martins, A.F.; Dias, D.M.; Morfin, J.-F.; Lacerda, S.; Laurents, D.V.; Tóth, É.; Geraldes, C.F.G.C. Interaction of PiB-Derivative Metal Complexes with Beta-Amyloid Peptides: Selective Recognition of the Aggregated Forms. Chem. A Eur. J. 2015, 21, 5413-5422. [CrossRef] [PubMed]

62. Wadghiri, Y.Z.; Sigurdsson, E.M.; Sadowski, M.; Elliott, J.I.; Li, Y.; Scholtzova, H.; Tang, C.Y.; Aguinaldo, G.; Pappolla, M.; Duff, K.; et al. Detection of Alzheimer's amyloid in transgenic mice using magnetic resonance microimaging. Magn. Reson. Med. 2003, 50, 293-302. [CrossRef] [PubMed]

63. Yao, N.; Xiao, W.; Wang, X.; Marik, J.; Park, S.H.; Takada, Y.; Lam, K.S. Discovery of Targeting Ligands for Breast Cancer Cells Using the One-Bead One-Compound Combinatorial Method. J. Med. Chem. 2009, 52, 126-133. [CrossRef] [PubMed]

64. Delehanty, J.B.; Boeneman, K.; Bradburne, C.E.; Robertson, K.; Bongard, J.E.; Medintz, I.L. Peptides for specific intracellular delivery and targeting of nanoparticles: Implications for developing nanoparticle-mediated drug delivery. Ther. Deliv. 2010, 1, 411-433. [CrossRef] [PubMed]

65. Olmedo, I.; Araya, E.; Sanz, F.; Medina, E.; Arbiol, J.; Toledo, P.; Álvarez-Lueje, A.; Giralt, E.; Kogan, M.J. How Changes in the Sequence of the Peptide CLPFFD-NH2 Can Modify the Conjugation and Stability of Gold Nanoparticles and Their Affinity for $\beta$-Amyloid Fibrils. Bioconjug. Chem. 2008, 19, 1154-1163. [CrossRef] [PubMed] 
66. Skaat, H.; Shafir, G.; Margel, S. Acceleration and inhibition of amyloid- $\beta$ fibril formation by peptide-conjugated fluorescent-maghemite nanoparticles. J. Nanopart. Res. 2011, 13, 3521-3534. [CrossRef]

67. Plissonneau, M.; Pansieri, J.; Heinrich-Balard, L.; Morfin, J.-F.; Stransky-Heilkron, N.; Rivory, P.; Mowat, P.; Dumoulin, M.; Cohen, R.; Allémann, É.; et al. Gd-nanoparticles functionalization with specific peptides for B-amyloid plaques targeting. J. Nanobiotechnol. 2016, 14, 60. [CrossRef] [PubMed]

68. Xia, N.; Wang, X.; Zhou, B.; Wu, Y.; Mao, W.; Liu, L. Electrochemical Detection of Amyloid- $\beta$ Oligomers Based on the Signal Amplification of a Network of Silver Nanoparticles. ACS Appl. Mater. Interfaces 2016, 8, 19303-19311. [CrossRef] [PubMed]

69. Fukumoto, H.; Tokuda, T.; Kasai, T.; Ishigami, N.; Hidaka, H.; Kondo, M.; Allsop, D.; Nakagawa, M. High-molecular-weight $\beta$-amyloid oligomers are elevated in cerebrospinal fluid of Alzheimer patients. FASEB J. 2010, 24, 2716-2726. [CrossRef] [PubMed]

70. An, Y.; Jiang, X.; Bi, W.; Chen, H.; Jin, L.; Zhang, S.; Wang, C.; Zhang, W. Sensitive electrochemical immunosensor for $\alpha$-synuclein based on dual signal amplification using PAMAM dendrimer-encapsulated $\mathrm{Au}$ and enhanced gold nanoparticle labels. Biosens. Bioelectron. 2012, 32, 224-230. [CrossRef] [PubMed]

71. Yang, S.-Y.; Chiu, M.-J.; Lin, C.-H.; Horng, H.-E.; Yang, C.-C.; Chieh, J.-J.; Chen, H.-H.; Liu, B.-H. Development of an ultra-high sensitive immunoassay with plasma biomarker for differentiating Parkinson disease dementia from Parkinson disease using antibody functionalized magnetic nanoparticles. J. Nanobiotechnol. 2016, 14, 41. [CrossRef] [PubMed]

72. Poduslo, J.F.; Hultman, K.L.; Curran, G.L.; Preboske, G.M.; Chamberlain, R.; Marjańska, M.; Garwood, M.; Jack, C.R.; Wengenack, T.M. Targeting Vascular Amyloid in Arterioles of Alzheimer Disease Transgenic Mice with Amyloid $\beta$ Protein Antibody-Coated Nanoparticles. J. Neuropathol. Exp. Neurol. 2011, 70, 653-661. [CrossRef] [PubMed]

73. Zameer, A.; Kasturirangan, S.; Emadi, S.; Nimmagadda, S.V.; Sierks, M.R. Anti-oligomeric A $\beta$ Single-chain Variable Domain Antibody Blocks A $\beta$-induced Toxicity Against Human Neuroblastoma Cells. J. Mol. Boil. 2008, 384, 917-928. [CrossRef] [PubMed]

74. Domanska, K.; Vanderhaegen, S.; Srinivasan, V.; Pardon, E.; Dupeux, F.; Marquez, J.A.; Giorgetti, S.; Stoppini, M.; Wyns, L.; Bellotti, V.; et al. Atomic structure of a nanobody-trapped domain-swapped dimer of an amyloidogenic $32-$ microglobulin variant. Proc. Natl. Acad. Sci. USA 2011, 108, 1314-1319. [CrossRef] [PubMed]

75. Muyldermans, S. Single domain camel antibodies: Current status. Rev. Mol. Biotechnol. 2001, 74, $277-302$. [CrossRef]

76. Muyldermans, S. Nanobodies: Natural Single-Domain Antibodies. Annu. Rev. Biochem. 2013, 82, $775-797$. [CrossRef] [PubMed]

77. Siontorou, C.G. Nanobodies as novel agents for disease diagnosis and therapy. Int. J. Nanomed. 2013, 8, 4215-4227. [CrossRef] [PubMed]

78. Habicht, G.; Haupt, C.; Friedrich, R.P.; Hortschansky, P.; Sachse, C.; Meinhardt, J.; Wieligmann, K.; Gellermann, G.P.; Brodhun, M.; Götz, J.; et al. Directed selection of a conformational antibody domain that prevents mature amyloid fibril formation by stabilizing A $\beta$ protofibrils. Proc. Natl. Acad. Sci. USA 2007, 104, 19232-19237. [CrossRef] [PubMed]

79. Pal, M.K.; Rashid, M.; Bisht, M. Multiplexed magnetic nanoparticle-antibody conjugates (MNPs-ABS) based prognostic detection of ovarian cancer biomarkers, CA-125, $\beta-2 \mathrm{M}$ and ApoA1 using fluorescence spectroscopy with comparison of surface plasmon resonance (SPR) analysis. Biosens. Bioelectron. 2015, 73, 146-152. [CrossRef] [PubMed]

80. Kepe, V.; Moghbel, M.C.; Långström, B.; Zaidi, H.; Vinters, H.V.; Huang, S.-C.; Satyamurthy, N.; Doudet, D.; Mishani, E.; Cohen, R.M.; et al. Amyloid- $\beta$ Positron Emission Tomography Imaging Probes: A Critical Review. J. Alzheimer's Dis. 2013, 36, 613-631. [CrossRef] [PubMed]

81. Hsiao, I.-T.; Huang, C.-C.; Hsieh, C.-J.; Wey, S.-P.; Kung, M.-P.; Yen, T.-C.; Lin, K.-J. Perfusion-like template and standardized normalization-based brain image analysis using 18F-florbetapir (AV-45/Amyvid) PET. Eur. J. Nucl. Med. Mol. Imaging 2013, 40, 908-920. [CrossRef] [PubMed]

82. De Lartigue, J. Flutemetamol (18F): A $\beta$-amyloid positron emission tomography tracer for Alzheimer's and dementia diagnosis. Drugs Today 2014, 50, 219-229. [CrossRef] [PubMed] 
83. Leuzy, A.; Zimmer, E.R.; Heurling, K.; Rosa-Neto, P.; Gauthier, S. Use of amyloid PET across the spectrum of Alzheimer's disease: Clinical utility and associated ethical issues. Amyloid 2014, 21, 143-148. [CrossRef] [PubMed]

84. Kantarci, K.; Yang, C.; Schneider, J.A.; Senjem, M.L.; Reyes, D.A.; Lowe, V.J.; Barnes, L.L.; Aggarwal, N.T.; Bennett, D.A.; Smith, G.E.; et al. Ante mortem amyloid imaging and $\beta$-amyloid pathology in a case with dementia with Lewy bodies. Neurobiol. Aging 2012, 33, 878-885. [CrossRef] [PubMed]

85. Higuchi, M.; Iwata, N.; Matsuba, Y.; Sato, K.; Sasamoto, K.; Saido, T.C. ${ }^{19} \mathrm{~F}$ and ${ }^{1} \mathrm{H}$ MRI detection of amyloid $\beta$ plaques in vivo. Nat. Neurosci. 2005, 8, 527-533. [CrossRef] [PubMed]

86. El Tayara, N.E.T.; Delatour, B.; Le Cudennec, C.; Guégan, M.; Volk, A.; Dhenain, M. Age-related evolution of amyloid burden, iron load, and MR relaxation times in a transgenic mouse model of Alzheimer's disease. Neurobiol. Dis. 2006, 22, 199-208. [CrossRef] [PubMed]

87. Chamberlain, R.; Reyes, D.; Curran, G.L.; Marjanska, M.; Wengenack, T.M.; Poduslo, J.F.; Garwood, M.; Jack, C.R. Comparison of amyloid plaque contrast generated by $\mathrm{T}_{2}$-weighted, $\mathrm{T}_{1}$-weighted, and susceptibility-weighted imaging methods in transgenic mouse models of Alzheimer's disease. Magn. Reson. Med. 2009, 61, 1158-1164. [CrossRef] [PubMed]

88. Dudeffant, C.; Vandesquille, M.; Herbert, K.; Garin, C.M.; Alves, S.; Blanchard, V.; Comoy, E.E.; Petit, F.; Dhenain, M. Contrast-enhanced MR microscopy of amyloid plaques in five mouse models of amyloidosis and in human Alzheimer's disease brains. Sci. Rep. 2017, 7, 4955. [CrossRef] [PubMed]

89. Jack, C.R.; Wengenack, T.M.; Reyes, D.A.; Garwood, M.; Curran, G.L.; Borowski, B.J.; Lin, J.; Preboske, G.M.; Holasek, S.S.; Adriany, G.; et al. In vivo Magnetic Resonance Microimaging of Individual Amyloid Plaques in Alzheimer's Transgenic Mice. J. Neurosci. 2005, 25, 10041-10048. [CrossRef] [PubMed]

90. Lee, S.-P.; Falangola, M.F.; Nixon, R.A.; Duff, K.; Helpern, J.A. Visualization of $\beta$-amyloid plaques in a transgenic mouse model of Alzheimer's disease using MR microscopy without contrast reagents. Magn. Reson. Med. 2004, 52, 538-544. [CrossRef] [PubMed]

91. Santin, M.D.; Debeir, T.; Bridal, S.L.; Rooney, T.; Dhenain, M. Fast in vivo imaging of amyloid plaques using $\mu$-MRI Gd-staining combined with ultrasound-induced blood-brain barrier opening. NeuroImage 2013, 79, 288-294. [CrossRef] [PubMed]

92. Wadghiri, Y.Z.; Li, J.; Wang, J.; Hoang, D.M.; Sun, Y.; Xu, H.; Tsui, W.; Li, Y.; Boutajangout, A.; Wang, A.; et al. Detection of Amyloid Plaques Targeted by Bifunctional USPIO in Alzheimer's Disease Transgenic Mice Using Magnetic Resonance Microimaging. PLoS ONE 2013, 8, e57097. [CrossRef] [PubMed]

93. Yang, J.; Zaim Wadghiri, Y.; Minh Hoang, D.; Tsui, W.; Sun, Y.; Chung, E.; Li, Y.; Wang, A.; de Leon, M.; Wisniewski, T. Detection of amyloid plaques targeted by USPIO-A $\beta 1-42$ in Alzheimer's disease transgenic mice using magnetic resonance microimaging. NeuroImage 2011, 55, 1600-1609. [CrossRef] [PubMed]

94. Sillerud, L.O.; Solberg, N.O.; Chamberlain, R.; Orlando, R.A.; Heidrich, J.E.; Brown, D.C.; Brady, C.I.; Vander Jagt, T.A.; Garwood, M.; Vander Jagt, D.L. SPION-Enhanced Magnetic Resonance Imaging of Alzheimer's Disease Plaques in A $\beta P P / P S-1$ Transgenic Mouse Brain. J. Alzheimer's Dis. 2013, 34, 349-365. [CrossRef] [PubMed]

95. Kim, J.-H.; Ha, T.L.; Im, G.H.; Yang, J.; Seo, S.W.; Lee, I.S.; Lee, J.H. Magnetic resonance imaging of amyloid plaques using hollow manganese oxide nanoparticles conjugated with antibody a $\beta 1-40$ in a transgenic mouse model. NeuroReport 2013, 24, 16. [CrossRef] [PubMed]

96. Larbanoix, L.; Burtea, C.; Laurent, S.; Van Leuven, F.; Toubeau, G.; Elst, L.V.; Muller, R.N. Potential amyloid plaque-specific peptides for the diagnosis of Alzheimer's disease. Neurobiol. Aging 2010, 31, 1679-1689. [CrossRef] [PubMed]

97. Ansciaux, E.; Burtea, C.; Laurent, S.; Crombez, D.; Nonclercq, D.; Elst, L.V.; Muller, R.N. In vitro and in vivo characterization of several functionalized ultrasmall particles of iron oxide, vectorized against amyloid plaques and potentially able to cross the blood-brain barrier: Toward earlier diagnosis of Alzheimer's disease by molecular imaging. Contrast Media Mol. Imaging 2015, 10, 211-224. [CrossRef] [PubMed]

98. André, S.; Ansciaux, E.; Saidi, E.; Larbanoix, L.; Stanicki, D.; Nonclercq, D.; Vander Elst, L.; Laurent, S.; Muller, R.N.; Burtea, C. Validation by Magnetic Resonance Imaging of the Diagnostic Potential of a Heptapeptide-Functionalized Imaging Probe Targeted to Amyloid- $\beta$ and Able to Cross the Blood-Brain Barrier. J. Alzheimer's Dis. 2017, 60, 1547-1565. [CrossRef] [PubMed] 
99. Skaat, H.; Corem-Slakmon, E.; Grinberg, I.; Last, D.; Goez, D.; Mardor, Y.; Margel, S. Antibody-conjugated, dual-modal, near-infrared fluorescent iron oxide nanoparticles for antiamyloidgenic activity and specific detection of amyloid- $\beta$ fibrils. Int. J. Nanomed. 2013, 8, 4063-4076. [CrossRef]

100. Salerno, M.; Santo Domingo Porqueras, D. Alzheimer's disease: The use of contrast agents for magnetic resonance imaging to detect amyloid beta peptide inside the brain. Coord. Chem. Rev. 2016, 327-328, 27-34. [CrossRef]

101. Lam, T.; Pouliot, P.; Avti, P.K.; Lesage, F.; Kakkar, A.K. Superparamagnetic iron oxide based nanoprobes for imaging and theranostics. Adv. Colloid Interface Sci. 2013, 199-200, 95-113. [CrossRef] [PubMed]

102. FDA Identifies No Harmful Effects to Date with Brain Retention of Gadolinium-Based Contrast Agents for MRIs; Review to Continue. FDA Drug Safety Communication. 27 July 2017. Available online: https: / / www.fda.gov / Drugs/DrugSafety/ucm559007.htm (accessed on 17 September 2018).

103. Zhou, Z.; Lu, Z.-R. Gadolinium-based contrast agents for magnetic resonance cancer imaging. Wiley Interdiscip. Rev. Nanomed. Nanobiotechnol. 2013, 5, 1-18. [CrossRef] [PubMed]

104. Sancey, L.; Kotb, S.; Truillet, C.; Appaix, F.; Marais, A.; Thomas, E.; van der Sanden, B.; Klein, J.-P.; Laurent, B.; Cottier, M.; et al. Long-Term in vivo Clearance of Gadolinium-Based AGuIX Nanoparticles and Their Biocompatibility after Systemic Injection. ACS Nano 2015, 9, 2477-2488. [CrossRef] [PubMed]

105. Poduslo, J.F.; Wengenack, T.M.; Curran, G.L.; Wisniewski, T.; Sigurdsson, E.M.; Macura, S.I.; Borowski, B.J.; Jack, C.R. Molecular Targeting of Alzheimer's Amyloid Plaques for Contrast-Enhanced Magnetic Resonance Imaging. Neurobiol. Dis. 2002, 11, 315-329. [CrossRef] [PubMed]

106. Vithanarachchi, S.M.; Allen, M.J. A multimodal, $\beta$-amyloid-targeted contrast agent. Chem. Commun. 2013, 49, 4148-4150. [CrossRef] [PubMed]

107. Ramakrishnan, M.; Wengenack, T.M.; Kandimalla, K.K.; Curran, G.L.; Gilles, E.J.; Ramirez-Alvarado, M.; Lin, J.; Garwood, M.; Jack, C.R., Jr.; Poduslo, J.F. Selective Contrast Enhancement of Individual Alzheimer's Disease Amyloid Plaques Using a Polyamine and Gd-DOTA Conjugated Antibody Fragment Against Fibrillar A 342 for Magnetic Resonance Molecular Imaging. Pharm. Res. 2008, 25, 1861. [CrossRef] [PubMed]

108. Lux, F.; Mignot, A.; Mowat, P.; Louis, C.; Dufort, S.; Bernhard, C.; Denat, F.; Boschetti, F.; Brunet, C.; Antoine, R.; et al. Ultrasmall Rigid Particles as Multimodal Probes for Medical Applications. Angew. Chem. Int. Ed. 2011, 50, 12299-12303. [CrossRef] [PubMed]

109. LeDuc, G.; Roux, S.; Paruta-Tuarez, A.; Dufort, S.; Brauer, E.; Marais, A.; Truillet, C.; Sancey, L.; Perriat, P.; Lux, F.; et al. Advantages of gadolinium based ultrasmall nanoparticles vs molecular gadolinium chelates for radiotherapy guided by MRI for glioma treatment. Cancer Nanotechnol. 2014, 5, 4. [CrossRef] [PubMed]

110. Sancey, L.; Lux, F.; Kotb, S.; Roux, S.; Dufort, S.; Bianchi, A.; Crémillieux, Y.; Fries, P.; Coll, J.L.; Rodriguez-Lafrasse, C.; et al. The use of theranostic gadolinium-based nanoprobes to improve radiotherapy efficacy. BJR 2014, 87, 20140134. [CrossRef] [PubMed]

111. Truillet, C.; Bouziotis, P.; Tsoukalas, C.; Brugière, J.; Martini, M.; Sancey, L.; Brichart, T.; Denat, F.; Boschetti, F.; Darbost, U.; et al. Ultrasmall particles for Gd-MRI and ${ }^{68} \mathrm{Ga}-\mathrm{PET}$ dual imaging. Contrast Media Mol. Imaging 2015, 10, 309-319. [CrossRef] [PubMed]

112. Knight, M.J.; McCann, B.; Kauppinen, R.A.; Coulthard, E.J. Magnetic Resonance Imaging to Detect Early Molecular and Cellular Changes in Alzheimer's Disease. Front. Aging Neurosci. 2016, 8, 139. [CrossRef] [PubMed]

113. Bianchi, A.; Moncelet, D.; Lux, F.; Plissonneau, M.; Rizzitelli, S.; Ribot, E.J.; Tassali, N.; Bouchaud, V.; Tillement, O.; Voisin, P.; et al. Orotracheal administration of contrast agents: A new protocol for brain tumor targeting. NMR Biomed. 2015, 28, 738-746. [CrossRef] [PubMed]

114. Hynynen, K.; McDannold, N.; Vykhodtseva, N.; Jolesz, F.A. Noninvasive MR Imaging-guided Focal Opening of the Blood-Brain Barrier in Rabbits. Radiology 2001, 220, 640-646. [CrossRef] [PubMed]

115. McDannold, N.; Arvanitis, C.D.; Vykhodtseva, N.; Livingstone, M.S. Temporary disruption of the blood-brain barrier by use of ultrasound and microbubbles: Safety and efficacy evaluation in rhesus macaques. Cancer Res. 2012. [CrossRef] [PubMed]

116. Lipsman, N.; Meng, Y.; Bethune, A.J.; Huang, Y.; Lam, B.; Masellis, M.; Herrmann, N.; Heyn, C.; Aubert, I.; Boutet, A.; et al. Blood-brain barrier opening in Alzheimer's disease using MR-guided focused ultrasound. Nat. Commun. 2018, 9, 2336. [CrossRef] [PubMed] 
117. Marty, B.; Larrat, B.; Van Landeghem, M.; Robic, C.; Robert, P.; Port, M.; Le Bihan, D.; Pernot, M.; Tanter, M.; Lethimonnier, F.; et al. Dynamic Study of Blood-Brain Barrier Closure after its Disruption using Ultrasound: A Quantitative Analysis. J. Cereb. Blood Flow Metab. 2012, 32, 1948-1958. [CrossRef] [PubMed]

118. Borchelt, D.R.; Ratovitski, T.; van Lare, J.; Lee, M.K.; Gonzales, V.; Jenkins, N.A.; Copeland, N.G.; Price, D.L.; Sisodia, S.S. Accelerated Amyloid Deposition in the Brains of Transgenic Mice Coexpressing Mutant Presenilin 1 and Amyloid Precursor Proteins. Neuron 1997, 19, 939-945. [CrossRef]

119. Nel, A.; Xia, T.; Mädler, L.; Li, N. Toxic Potential of Materials at the Nanolevel. Science 2006, 311, $622-627$. [CrossRef] [PubMed]

120. Xiao, G.G.; Wang, M.; Li, N.; Loo, J.A.; Nel, A.E. Use of Proteomics to Demonstrate a Hierarchical Oxidative Stress Response to Diesel Exhaust Particle Chemicals in a Macrophage Cell Line. J. Boil. Chem. 2003, 278, 50781-50790. [CrossRef] [PubMed]

(C) 2018 by the authors. Licensee MDPI, Basel, Switzerland. This article is an open access article distributed under the terms and conditions of the Creative Commons Attribution (CC BY) license (http://creativecommons.org/licenses/by/4.0/). 